\title{
Reinstatement of Aloe graciliflora Groenew. (Asphodelaceae: Alooideae), a maculate aloe from north-east South Africa
}

\author{
Ronell R. Klopper ${ }^{1,2}$, Olwen M. Grace ${ }^{3}$, Gideon F. Smith ${ }^{1,2,5}$ and Estrela Figueiredo ${ }^{4,5}$ \\ ${ }_{1}^{1}$ Biosystematics Research and Biodiversity Collections Division, South African National Biodiversity Institute, \\ Private Bag X101, Pretoria, 0001 South Africa (email: R.Klopper@sanbi.org.za; G.Smith@ sanbi.org.za). \\ ${ }^{2}$ H.G.W.J. Schweickerdt Herbarium, Department of Plant Science, University of Pretoria, Pretoria, 0002 \\ South Africa. \\ ${ }^{3}$ Royal Botanic Gardens, Kew, Richmond, Surrey, TW9 3AB, UK / Natural History Museum of Denmark, \\ Sølvgade 83, Copenhagen, Denmark (email: o.grace@kew.org). \\ ${ }^{4}$ Department of Botany, PO Box 77000, Nelson Mandela Metropolitan University, Port Elizabeth, 6031 \\ South Africa (email: estrelafigueiredo@ hotmail.com). \\ ${ }^{5}$ Centre for Functional Ecology, Departamento de Ciências da Vida, Universidade de Coimbra, 3001-455 \\ Coimbra, Portugal.
}

Summary: Aloe graciliflora Groenew., which has previously been included in the synonymy of A. greatheadii Schönland var. davyana (Schönland) Glen \& D.S.Hardy, is here reinstated. This species is adapted to the climatic extremes of South Africa's eastern Highveld where it occurs southward from near Dullstroom to WatervalBoven and Badplaas, and westward to Carolina. Morphologically it differs from $A$. greatheadii var. davyana by having larger flowers that generally lack the greyish longitudinal stripes, the flower colour being more intensely red, and by being a more robust plant in all respects.

Zusammenfassung: Aloe graciliflora Groenew., die früher als Synonym von $A$. greatheadii Schönland var. davyana (Schönland) Glen \& D.S.Hardy betrachtet wurde, wird hier wieder als Art interpretiert. Die Art ist an die klimatischen Extreme des östlichen Higvelds von Südafrika angepasst, wo sie von nahe Dullstroom nach Süden bis Waterval-Boven und Badplaas, und nach Westen bis Carolina vorkommt. Morphologisch unterscheidet sich die Art von A. greatheadii var. davyana durch grössere Blüten, die in der Regel keine gräuliche Längsstreifung zeigen und deshalb intensiver rot sind, sowie durch die in allen Belangen robusteren Pflanzen.

\section{Introduction}

The complex of maculate aloes is one of the most taxonomically challenging in the genus Aloe L.
(Grace et al., 2009, 2010). Species circumscription tends to be vague and contentious as populations of one species seemingly intergrade and hybridize with populations of neighbouring species. Where maculate aloes occur sympatrically this is a particular problem, for example in the northern and northeastern parts of South Africa, which are host to some of the densest concentrations of Aloe species globally (Holland, 1978).

As part of their revision of Aloe L. in southern Africa, Glen \& Hardy (2000) earlier proposed several changes of rank and status for some maculate aloe species (Glen \& Hardy, 1987). One of these proposals suggested the inclusion of Aloe graciliflora Groenew. in the synonymy of $A$. greatheadii Schönland var. davyana (Schönland) Glen \& D.S.Hardy (1987). However, the expanded concept of $A$. greatheadii itself has since not been consistently accepted, with some authors preferring specific rank for Aloe davyana Schönland (Smith \& Correia, 1988; Smith \& Van Wyk, 2008; Grace et al., 2011) and segregate taxa also included in the synonymy of $A$. greatheadii var. davyana, such as $A$. longibracteata Pole Evans and A. verdoorniae Reynolds. Although there are several taxa debatably included in the synonymy of A. greatheadii var. davyana and reinstatement of some of these at specific rank may be warranted, we deal here only with $A$. graciliflora. This is deliberate, as we feel it is important to assess the status of each of the relevant taxa on their own merit, rather than treating them as a group. Bearing the importance of the bigger picture of 
maculate aloe taxonomy in mind, the decision to reinstate $A$. graciliflora at species rank was taken only after the taxon was evaluated against all entities currently included in the broad concept of A. greatheadii var. davyana.

\section{Distribution and habitat}

Aloe graciliflora was first described by Groenewald (1936) from material collected near Dullstroom in the then Eastern Transvaal (now Mpumalanga). It occurs from Dullstroom in the north to Badplaas in the south, and in a strip from near Belfast and Carolina in the west to Machadodorp and Waterval-Boven in the east. Elevation varies from over $2,100 \mathrm{~m}$ above sea level (asl) near Dullstroom to about 1,600 m asl near Badplaas on the eastern slopes of the Mpumalanga Drakensberg (Figure 1).

The geographical distribution range of $A$. graciliflora extends from one of the coldest regions on the Highveld of South Africa's eastern interior, into the subtropical Lowveld towards Badplaas. It therefore spans a considerable temperature differential, with mean temperatures ranging from $\pm 25^{\circ} \mathrm{C}$ in summer to $\pm 2^{\circ} \mathrm{C}$ in winter. Aloe graciliflora occurs near the western boundary of the Barberton Centre of Endemism (Van Wyk \& Smith, 2001) but, significantly, does not seem to enter this largely climatically moderate Centre.
Aloe graciliflora grows on rocky outcrops and sandstone ridges in Lydenburg Montane Grassland and KaNgwane Montane Grassland (Mucina \& Rutherford, 2006) (Figure 2). It is well adapted to survive regular fires in this habitat (Figure 3).

\section{Characters and variation}

Morphologically, A. graciliflora is a small to medium-sized aloe that can reach a height of $300 \mathrm{~mm}$ in the vegetative condition. When in flower, the branched or simple inflorescence can increase the plant height to about $1.1 \mathrm{~m}$ (Figure 4). The lower leaf surfaces are generally a milky green colour and can vary from unspotted to copiously spotted, while the upper surfaces vary from light to dull green with white spots often arranged in somewhat confluent cross bands (Figures 5 \& 6). Like many short-stemmed aloes, the leaf tips die back in winter, usually persisting on the leaf and becoming recurved and twisted. Flowers are narrower and longer than those of $A$. greatheadii var. davyana, uniformly coloured and lack the greyish longitudinal stripes found on flowers of that species (Figures $7 \& 8$ ). See Table 1 for further characters distinguishing between $A$. graciliflora and $A$. greatheadii var. davyana.

As originally circumscribed by Groenewald (1936, 1941), the name A. graciliflora is applied

Table 1. Characters distinguishing Aloe graciliflora and A. greatheadii var. davyana

\begin{tabular}{|c|c|c|}
\hline Character & A. graciliflora & A. greatheadii var. davyana \\
\hline $\begin{array}{l}\text { Leaf } \\
\text { (upper surface) }\end{array}$ & $\begin{array}{l}\text { bright, shiny green, with whitish } \\
\text { oblong spots, varying from irregularly } \\
\text { scattered to more or less arranged in } \\
\text { undulating transverse bands }\end{array}$ & $\begin{array}{l}\text { green to dull brownish green, with } \\
\text { numerous oblong, white spots, some- } \\
\text { times arranged in interrupted, wavy } \\
\text { transverse bands }\end{array}$ \\
\hline $\begin{array}{l}\text { Leaf } \\
\text { (lower surface) }\end{array}$ & $\begin{array}{l}\text { pale milky green, varying from unspot- } \\
\text { ted and somewhat obscurely lineate to } \\
\text { copiously spotted with spots arranged } \\
\text { more or less in wavy transverse bands }\end{array}$ & $\begin{array}{l}\text { pale glaucous green, obscurely lineate, } \\
\text { without spots }\end{array}$ \\
\hline Inflorescence & $\begin{array}{l}\text { 0.6-0.8 m high, simple to mostly } \\
\text { 3-branched from middle or below }\end{array}$ & $\begin{array}{l}0.6-1.0 \mathrm{~m} \text { high, } 3-5 \text {-branched from below } \\
\text { middle }\end{array}$ \\
\hline Perianth colour & $\begin{array}{l}\text { deep pink to dull orange-red, with a } \\
\text { bloom }\end{array}$ & $\begin{array}{l}\text { pale pink to dull red, greenish to greyish } \\
\text { striped }\end{array}$ \\
\hline Flower dimensions & $\begin{array}{l}\text { up to } 52 \mathrm{~mm} \text { long, } 9-10 \mathrm{~mm} \text { across } \\
\text { ovary, constricted above ovary to } \\
5 \mathrm{~mm} \text { to form subglobose basal } \\
\text { swelling, slightly widening to } 7 \mathrm{~mm} \\
\text { towards throat }\end{array}$ & $\begin{array}{l}32-35 \mathrm{~mm} \text { long, } 7 \mathrm{~mm} \text { across ovary, } \\
\text { constricted above ovary to } 5 \mathrm{~mm} \text {, } \\
\text { widening to } 7 \mathrm{~mm} \text { towards throat }\end{array}$ \\
\hline $\begin{array}{l}\text { Outer perianth } \\
\text { segments }\end{array}$ & free for $12-15 \mathrm{~mm}$ & free for $10 \mathrm{~mm}$ \\
\hline Floral bracts & up to $30 \mathrm{~mm}$ long & 20-25 mm long \\
\hline Pedicels & 25-30 mm long & 20-25 mm long \\
\hline
\end{tabular}



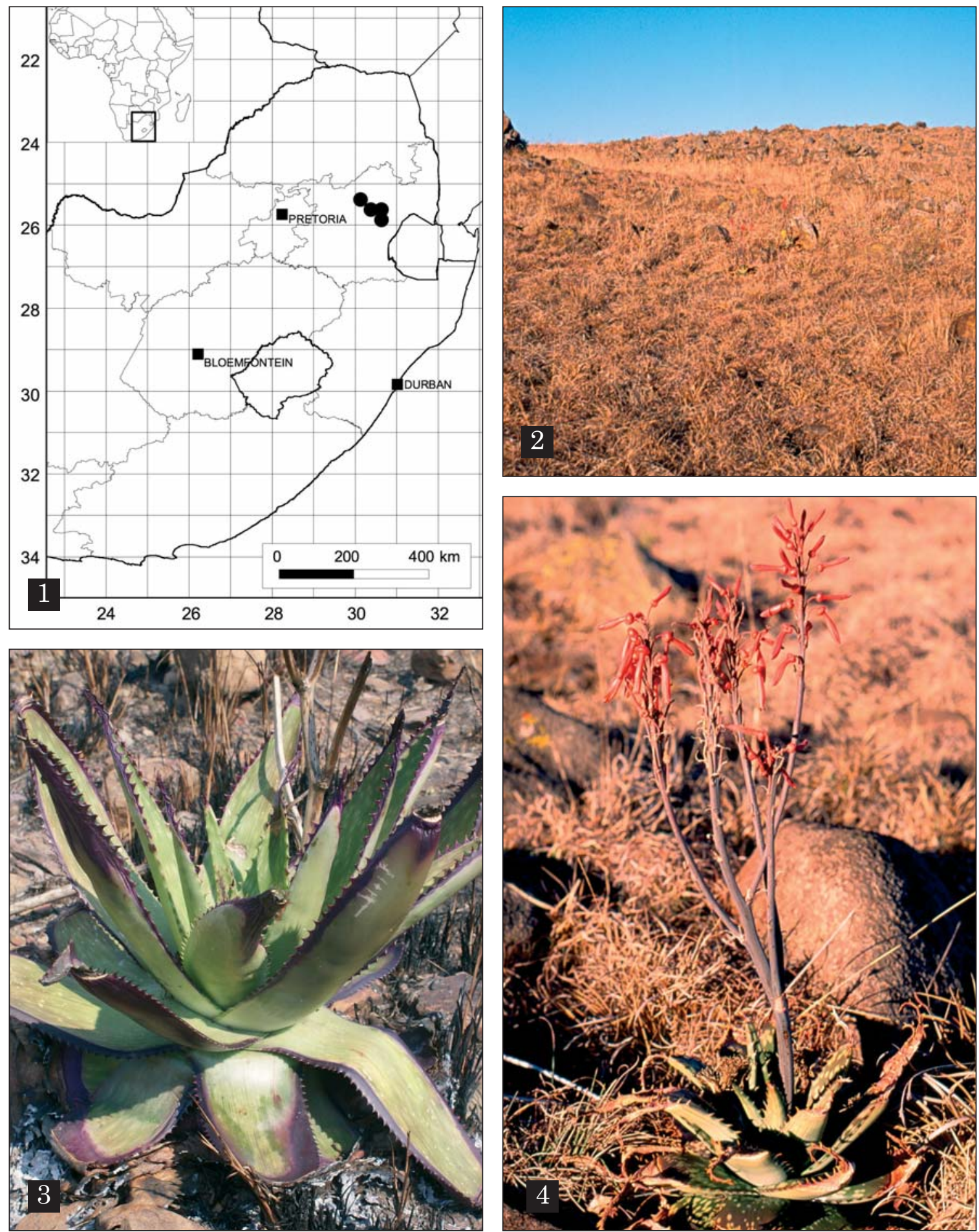

Figure 1. Geographical distribution of $A$. graciliflora $(\bullet)$. Figure 2. A. graciliflora (middle ground) flowering in its natural grassland habitat near Machadodorp in Mpumalanga. Figure 3. A. graciliflora is well adapted to survive regular fires in its natural habitat, as seen here near Machadodorp. Figure 4. A. graciliflora flowering in habitat near Machadodorp in the first week of August 2006. Photos: Gideon F. Smith. 
exclusively to the fairly small, early-summer (October to December) flowering plants that occur around Dullstroom in Mpumalanga. These plants are usually acaulescent and rosettes sucker to form groups. Subsequent workers, notably Reynolds (1950), have extended the concept to include more robust, earlier (i.e. late-winter, August) flowering specimens that occur further to the south, around Machadodorp, Waterval-Boven and Carolina. This form is more robust in all aspects, plants are usually solitary and can have stems of up to $0.2 \mathrm{~m}$. This broadening of the taxonomic concept of $A$. graciliflora does not seem unjustified. However, several disparate populations - larger plants, different flower colours - that occur within the natural distribution range of the species deviate from Groenewald's concept.

In broad phytogeographic terms, A. graciliflora is currently regarded as surrounded by A. davyana to the west, $A$. mutans Reynolds and $A$. longibracteata to the north, and $A$. barbertoniae Pole Evans and A. parvibracteata Schönland (and taxa currently included in it) to the east. Aloe graciliflora is not known to co-occur with any of these other maculate aloes. A suite of different maculate aloes occupies northern KwaZulu-Natal and the midlands of that province.

\section{Taxonomy and nomenclature}

Aloe graciliflora Groenew. in Tydskr. Wetensk. Kuns 14: 137-139 (1936). Groenewald: 102 (1941); Reynolds: 241-242 (1950 and later editions); Bornman \& Hardy: 102-103 (1971); Glen et al.: 98 (1995); Smith \& Van Wyk: 78 (2008); Grace et al.: 65 (2011).

Type: neotype selected by Glen et al. (1995): Transvaal (now Mpumalanga), Dullstroom, F.Z van der Merwe s.n. in PRE 24089 (PRE!).

Treated as a synonym of $A$. greatheadii Schönland var. davyana (Schönland) Glen \& D.S.Hardy by several authors: Glen \& Hardy: 490-491 (1987); Newton: 138-139 (2001); Glen \& Hardy: 56 (2000); Van Wyk \& Smith: 200 (2005); Grace: 115 (2009).

Small to medium-sized rosulate leaf succulent. Plants acaulescent or with short stem of up to $0.2 \mathrm{~m}$ long, rosettes solitary or suckering to form small groups. Leaves 15-20, densely rosulate, lanceolate-deltoid, up to $230 \mathrm{~mm}$ long, $100 \mathrm{~mm}$ broad at base; upper surface plane to slightly canaliculated, bright green, spotted, the spots oblong, whitish, varying from irregularly scattered to more or less arranged in undulating transverse bands; lower surface convex, paler green than the upper, varying from unspotted and somewhat obscurely lineate to, rarely, copiously spotted with the spots arranged more or less in wavy transverse bands; margins sinuate-dentate, the teeth brown, deltoid, pungent, about $5 \mathrm{~mm}$ long, $10 \mathrm{~mm}$ distant; exudate honey-coloured, dries yellowish. Inflorescence 1-2 simultaneously or successively, 600-800 mm high, erect, simple to mostly 3branched from the middle or lower, with the three racemes in the same plane, the lowest branch subtended at base by a pale brownish, thin, scarious bract, $60 \mathrm{~mm}$ long, $25 \mathrm{~mm}$ broad at base. Racemes cylindric-acuminate, up to $300 \mathrm{~mm}$ long, 80-90 $\mathrm{mm}$ in diameter, sub-densely flowered, the buds at first sub-erect, becoming horizontally disposed, with the open flowers cernuous to pendulous. Floral bracts the lowest deltoid-acuminate, thin, scarious, about 5-7-nerved, about $30 \mathrm{~mm}$ long, usually slightly longer than their pedicels. Pedicels lowest of terminal racemes $25-30 \mathrm{~mm}$ long, the colour of the perianth, longer and turning brownish in the fruit. Perianth deep pink to dull orange-red with a bloom, slender, up to 52 $\mathrm{mm}$ long, with sub-globose basal swelling 9-10 $\mathrm{mm}$ in diameter, constricted above the ovary to $5 \mathrm{~mm}$, thence slightly decurved and enlarging to $7 \mathrm{~mm}$ towards the throat; outer segments free for $12-15 \mathrm{~mm}$, usually with white marginal border, and sub-acute spreading apices; inner segments dorsally adnate to the outer for three-quarters of their length, broader than the outer and with broader white marginal border, the apices more obtuse and more spreading. Filaments pale lemon, filiform-flattened, the 3 inner narrower and lengthening in advance of the 3 outer, with the anthers in turn exserted 1-2 mm. Stigma at length exserted 1-2 mm. Ovary $10 \mathrm{~mm}$ long, $4 \mathrm{~mm}$ diameter, slightly tapering into the style, finely 6-grooved, green. Fruit not seen.

Flowering time: August and October to December.

Etymology: From Latin 'gracilis' (slender), '-florus' (flowered); refers to the slender flowers, that are longer and narrower as compared to those of A. greatheadii var. davyana.

Specimens examined: SOUTH AFRICA, MPUMALANGA.- 2530: Belfast district, near Dullstroom, (-AC), 1936-11-01, G.W. Reynolds 2162 (PRE); Dullstroom, grassland on stony welldrained soil, (-AC), 1982-10-25, H.G. Cameron 212 (PRE); Waterval-Boven, rocky slope 1 mile east of Waterval-Boven, (-CB), 1936-07-14, G.W. Reynolds 1965 (PRE); Waterval-Boven, 2 miles west of Waterval-Boven on road to WatervalOnder, (-CB), 1941-08-14, G.W. Reynolds 3894 \& 3895 (PRE); Lydenburg district, $\pm 8 \mathrm{~km}$ south of 

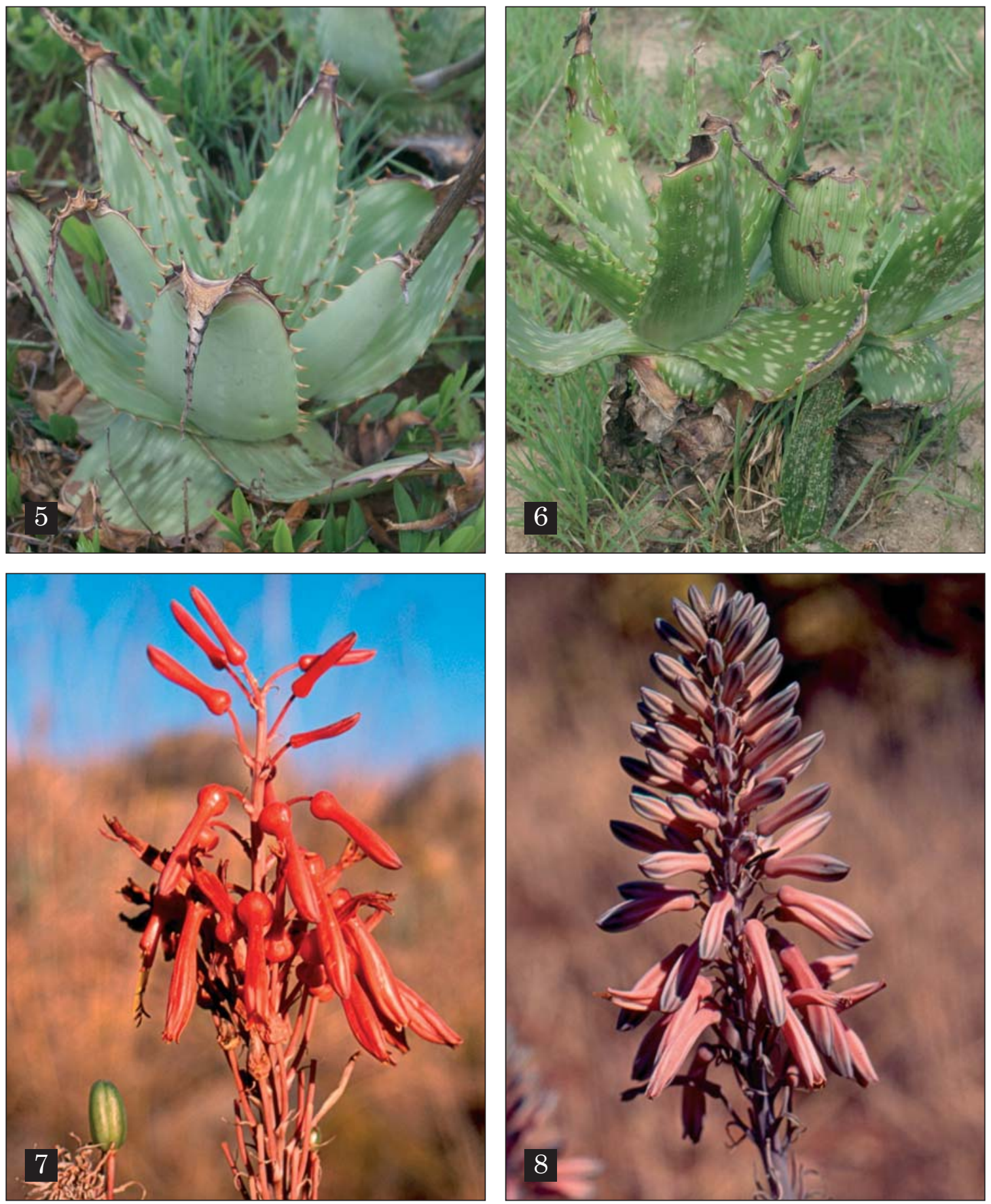

Figure 5. Solitary plant of A. graciliflora from Waterval Boven, showing the spotted upper surface of the leaves and unspotted lower surface. Figure 6. Suckering plants of A. graciliflora from Badplaas, showing the short stem, as well as leaves that are spotted on both surfaces. Figure 7. Close-up of an inflorescence of $A$. graciliflora. The flowers of this species are longer and generally more intensely reddish in colour than those of $A$. greatheadii var. davyana. Figure 8. Close-up of an inflorescence of A. greatheadii var. davyana. The flowers of this species are shorter and generally a more dull pinkish colour than those of $A$. graciliflora. Photos: Gideon F. Smith. 
Machadodorp on the eastern side of the road to Badplaas, (-CB), 2010-11-20, G.F. Smith \& E. Figueiredo 14 (PRE); Starvation Creek Nature Reserve, (-DA), 1978-08-02, J.P. Kluge 1354 (PRE); Between Barberton and Carolina, on rocky slopes 10 miles east of Badplaas, (-DC), 1935-08-21, G.W. Reynolds 1110 (PRE).

Common names: bontaalwyn (Afrikaans).

\section{References}

BornMan, H. \& HARDY, D.[S.] (1971). Aloes of the South African veld. Voortrekkerpers Johannesburg.

Glen, H.F. \& HARDY, D.S. (1987). Nomenclatural notes on three southern African representatives of the genus Aloe. S. Afr. J. Bot. 53: 489492.

GLEN, H.F. \& HARDY, D.S. (2000). Aloaceae (First part): Aloe. In Germishuizen, G. (ed.), Flora of southern Africa, Vol. 5, Part 1, Fascicle 1: 1-167. National Botanical Institute, South Africa.

Glen, H.F., Smith, G.F. \& Hardy, D.S. (1995). Asphodelaceae/Aloaceae. Typification of Aloe species described by B.H. Groenewald. Bothalia 25: 97-99.

Grace, O.M. (2009). Contributions to the systematics and biocultural value of Aloe L. (Asphodelaceae). Unpublished Ph.D. dissertation. University of Pretoria, Pretoria.

Grace, O.M., Klopper, R.R., Figueiredo, E. \& Smith, G.F. (2011). The aloe names book. Strelitzia 28. South African National Biodiversity Institute, Pretoria and the Royal Botanic Gardens, Kew, London.

Grace, O.M., Simmonds, M.S.J., Smith. G.F. \& VAN WyK, A.E. [Braam] (2009). Taxonomic significance of leaf surface morphology in Aloe section Pictae (Xanthorrhoeaceae). Bot. J. Linn. Soc. 160: 418-428.
Grace, O.M., Simmonds, M.S.J., Smith. G.F. \& VAN WYK, A.E. [Braam] (2010). Chemosystematic evaluation of Aloe section Pictae (Asphodelaceae). Biochem. Syst. Ecol. 38: 57-62.

Groenewald, B.H. (1936). Beskrywing van 'n nuwe makulaat-aloesoort van Oos- Transvaal [Aloe graciliflora Groenew.]. Tydskr. Wetensk. Kuns 14: 137-139.

Groenewald, B.H. (1941). Die aalwyne van SuidAfrika, Suidwes-Afrika, Portugees Oos-Afrika, Swaziland, Basoetoeland, en 'n spesiale ondersoek van die klassifikasie, chromosome and areale van die Aloe Maculatae. Nasionale Pers Beperk, Bloemfontein.

Holland, P.G. (1978). An evolutionary biogeography of the genus Aloe. J. Biogeog. 5: 213-226.

Mucina, L. \& Rutherford, M.C. (eds.). (2006). The vegetation of South Africa, Lesotho and Swaziland. Strelitzia 19. South African National Biodiversity Institute, Pretoria.

Newton, L.E. (2001). Aloe. In EGGLI, U. (ed.), Illustrated handbook of succulent plants: Monocotyledons. Pp. 103-186. SpringerVerlag, Berlin.

ReYnolds, G.W. (1950). The Aloes of South Africa. The Aloes of South Africa Book Fund, Johannesburg.

Smith, G. F. \& Correia, R.I. De S. (1988). Notes on the ecesis of Aloe davyana (Asphodelaceae: Alooideae) in seed-beds and under natural conditions. S. Afr. J. Sci. 84: 873.

Sмith, G. F. \& VAN WyK, A.E. [Braam]. (2008). Aloes in southern Africa. Struik Publishers, Cape Town.

VAN WyK, A.E. [Braam] \& SMith, G.F. (2001). Regions of floristic endemism in southern Africa. A review with emphasis on succulents. Umdaus Press, Hatfield.

VAN WyK, B-E. \& SMith, G.[F.] (2005). Guide to the aloes of South Africa. 2nd edition, 2nd impression. Briza Publications, Pretoria. 